\title{
PENGARUH PENDIDIKAN KESEHATAN MELALUI AUDIOVISUAL TERHADAP MOTIVASI REMAJA DALAM UPAYA PENCEGAHAN HIV/AIDS
}

\author{
Arif Wira Dinata ${ }^{1}$, Gamya Tri Utami ${ }^{2}$, Reni Zulfitri ${ }^{3}$ \\ ${ }^{1,2,3}$ Fakultas Keperawatan Universitas Riau \\ JL. Pattimura No. 9 Gedung G Pekanbaru Riau \\ Kode pos 28131 Indonesia \\ Email: arifwiradinata@gmail.com
}

\begin{abstract}
Abstrak
Pendidikan kesehatan merupakan suatu cara untuk mempengaruhi seseorang dengan memberikan informasi dan memberikan kesadaran untuk dapat mengadopsi dan berperilaku sehat yang dapat meningkatkan derajat kesehatannya. Tujuan penelitian ini dilakukan untuk mengetahui apakah ada pengaruh pemberian intervensi keperawatan berupa pendidikan kesehatan melalui media audiovisual terhadap motivasi remaja dalam pencegahan HIV/AIDS di SMA Negeri 9 Kota Pekanbaru dengan menggunakan desain quasy experiment melalui pendekatan non-equivalent control group. Teknik pengambilan sampel dengan cara stratified random sampling dengan jumlah responden 90 orang dan dibagi 2 kelompok, 45 orang kelompok eksperimen dan 45 orang kelompok kontrol dengan alat ukur kuesioner yang telah valid dan reliabel. Analisis data menggunakan analisis univariat dan analisis bivariat dengan menggunakan uji Wilcoxon dan T Independent. Hasil analisis univariat diperoleh sebagian besar umur responden 16 tahun sebanyak 43 orang (47,8\%), mayoritas berjenis kelamin perempuan sebanyak 59 orang $(65,6 \%)$, mayoritas beragama Islam sebanyak 79 orang $(87,8 \%)$, dan seluruh responden tinggal bersama keluarga sebanyak 90 orang (100\%). Analisis bivariat menunjukkan pendidikan kesehatan melalui audiovisual berpengaruh terhadap motivasi remaja dalam upaya pencegahan HIV/AIDS dengan $p$ value $(0,000)<\alpha(0,05)$. Hasil penelitian ini dapat dijadikan salah satu intervensi keperawatan terhadap peningkatan motivasi remaja untuk mencegah terinfeksi HIV/AIDS.
\end{abstract}

Kata Kunci : Audiovisual, HIV/AIDS, Motivasi, Pendidikan Kesehatan, Remaja

\begin{abstract}
Health education is one the way to influence a person by providing information and providing awareness to be able to adopt and behave healthily that can increase the degree of health. This research aims to find out if there is an effect of nursing intervention in the form of health education through audiovisual media on the motivation of adolescents in HIV/AIDS prevention in SMA Negeri 9 Pekanbaru. This research uses quasy experiment design through a non-equivalent control group approach. The sampling technique was stratified random sampling with 90 respondents and divided into 2 groups, 45 experiment groups and 45 control groups with valid and reliabel questionnaire measuring instruments. Data analysis uses univariate analysis and bivariate analysis using Wilcoxon and Independent $t$ tests. The results of the univariate analysis were obtained most of the aged 16-year respondents as many as 43 people (47.8\%), the majority of female genders as many as 59 people (65.6), the majority of the Islamic faith of 79 people (87.8), and all respondents living with family of 90 people (100\%). Results of bivariate analysis showing health education through audiovisual effect on the motivation of adolescents in the prevention of HIV/AIDS with P value $(0.000)<\alpha(0.05)$. The results of this research can be one of the nursing interventions that can be used to improve the motivation of adolescents to the prevention of HIV/AIDS.
\end{abstract}

Keywords: Audiovisual, HIV/AIDS, Motivation, Health education, Adolescents

\section{PENDAHULUAN}

Infeksi HIV (Human Immunodeficiency

Virus) dan penyakit AIDS (Acquired Immune

Deficiency Syndrome) sampai saat ini masih menjadi tantangan didunia kesehatan. Data kasus pada tahun 2017 tercatat 36,9 juta orang di dunia hidup dengan HIV dan 1,8 juta orang yang baru terinfeksi (UNAIDS, 2017). Prevalensi kasus 
Arif Wira Dinata, Gamya Tri Utami, Reni Zulfitri, Pengaruh Pendidikan Kesehatan Melalui Audiovisual Terhadap Motivasi Remaja Dalam Upaya Pencegahan HIV/AIDS

HIV tertinggi di Asia ditemukan di negara India dengan total 2,1 juta dan Indonesia berada di tingkat ketiga dengan total 630.000 kasus setelah China (UNAIDS, 2018).

Prevalensi penderita HIV dan penyakit AIDS di Indonesia tahun 2017 sebanyak 48.300 orang kasus HIV dan 9.280 orang kasus AIDS. Presentase kasus HIV paling tinggi terdapat pada rentang umur 25- 49 tahun $(69,3 \%)$, selanjutnya dikuti rentang umur 20-24 tahun (17,3\%). Sedangkan untuk presentase kasus AIDS paling tinggi terdapat pada rentang umur 30 sampai 39 tahun $(35,5 \%)$, dan untuk kedua pada rentang umur 20 sampai 29 tahun (30,5\%) dengan faktor resiko $43,5 \%$ tidak diketahui. Faktor resiko tertinggi terjadi pada lelaki seks dengan lelaki (LSL) sebesar 24,2\%. Kasus HIV terbanyak dijumpai pada jenis kelamin laki-laki yaitu dengan presentase $63,6 \%$ dan perempuan dengan presentase 36,4\%, selanjutnya untuk kasus AIDS, presentase kasus AIDS pada laki laki $68 \%$ dan presentase pada perempuan 31,9\% (Kemenkes RI, 2018).

Permasalahan kasus HIV/AIDS ini menjadi tantangan kesehatan di seluruh Indonesia, termasuk Provinsi Riau. Kasus HIV dan AIDS tertinggi di Riau sampai akhir tahun 2017 terdapat di Kota Pekanbaru dengan jumlah kumulatif sebanyak 2.612 kasus dengan rincian 1,406 kasus HIV dan 1,206 kasus AIDS. Presentase paling tinggi kasus HIV/AIDS terdapat pada rentang umur 25-49 tahun dan diikuti oleh rentang umur 20-24 tahun dengan faktor resiko penularan tertinggi pada kelompok homoseksual (Dinkes Kota Pekanbaru, 2018).

Infeksi HIV memerlukan waktu yang relatif lama sampai munculnya tanda-tanda klinis penyakit AIDS (Setiyorini, 2015). Pada saat awal infeksi penderita tampak sehat, bisa melakukan aktivitas normal tetapi sudah dapat menularkan kepada orang lain (Depkes RI, 2009). Jika seseorang diketahui menderita penyakit HIV/AIDS pada usia dewasa awal, penderita mulai terjangkit pada saat remaja dikarenakan masa inkubasi virus ini membutuhkan waktu 5-10 tahun. Dapat disimpulkan masa remaja merupakan resiko terbesar untuk terinfeksi HIV/AIDS jika tidak bisa menjaga diri dari faktor lingkungan yang kurang baik (Dinas Kesehatan Provinsi Riau, 2013).

Masa remaja ditandai dengan terjadinya kematangan seksual diusia 11 atau 12 tahun sampai usia 20 tahun, yang mana pada masa ini dikatakan masa peralihan dari masa kanak-kanak ke masa remaja (Soetjiningsih, 2010). Pada usia ini seseorang mengalami perubahan seperti fisik, biologis, kognitif, perilaku dan emosional yang kemudian akan tercermin pada sikap dan tingkah laku (Wong, 2009). Kenakalan yang terjadi pada remaja dipengaruhi oleh faktor internal (faktor yang asalnya dari dalam diri seseorang atau individu itu sendiri) dan faktor ekternal (faktor yang asalnya dari luar diri seseorang atau individu seperti pengaruh lingkungan).

Faktor resiko yang menyebabkan remaja tertularnya HIV/AIDS dari faktor lingkungan adalah remaja kurang terpaparnya informasi 
Jurnal Ners Indonesia, Vol. 12, No. 1, September 2021

mengenai kesehatan, infeksi yang ditimbulkan akibat hubungan seks bebas, dan pencegahan kehamilan (Willis, 2012). Kondisi seperti ini yang menjadikan remaja akan merespon dengan perilaku dan sikap yang salah seperti tindakan kriminalitas, minum-minuman keras atau miras, penggunaan narkotika, psikotropika dan obat terlarang, tawuran sesama remaja dan melakukan hubungan seksual diluar nikah yang mana tindakan ini beresiko untuk terinfeksi HIV/AIDS (Seotjiningsih, 2010). Rendahnya pengetahuan seseorang dapat membawa remaja kearah perilaku yang tidak sehat yang akan mengakibatkan mereka beresiko akan tertularnya HIV/AIDS, karena perilaku yang kurang baik disebabkan oleh kurangnya pengetahuan seseorang.

Salah satu fakor yang akan mempengaruhi motivasi seseorang adalah pengetahuan (Ferry \& Nursalam, 2008). Pengetahuan yang dimiliki seseorang akan memotivasi seseorang dengan membentuk suatu keyakinan untuk melakukan tindakan tertentu salah satunya adalah dalam tindakan pencegahan penyakit HIV/AIDS. Suatu tindakan yang biasa dilakukan untuk meningkatkan motivasi dan pengetahuan remaja terhadap cara pencegahan terinfeksi HIV dan penyakit AIDS adalah dengan memberikan suatu pendidikan kesehatan.

Pendidikan kesehatan ialah sebuah proses yang sudah direncanakan yang tujuannya untuk meningkatkan pengetahuan dan keahlian (life skills) dan menciptakan sebuah peluang (literacy). Tercapainya tujuan dalam pemberian pendidikan kesehatan dipengaruhi oleh banyak faktor, seperti faktor materi dan faktor metode yang diberikan, pemateri atau pendidik yang menyampaikan, dan alat atau media yang digunakan dalam menyampaikan suatu informasi (Notoatmodjo, 2010).

Media audiovisual adalah suatu media yang menyampaikan data informasi secara audiovisual atau pandang dengar (Setiawati \& Dermawan, 2008). Media audiovisual akan memberikan stimulus pada pendengaran dan penglihatan seseorang, sehingga hasil yang akan diterima akan lebih maksimal. Menurut Maulana (2009) indera penglihatan salah satu panca indera terbesar dalam menyalurkan ilmu pengetahuan yaitu sebesar $75 \%-87 \%$ sedangkan panca indera yang lainnya hanya sebesar 13\%-25\%.

Berdasarkan penelitian yang dilakukan Yulistasari (2014), bahwa pemberian pendidikan kesehatan menggunakan media audiovisual akan memberikan hasil yang lebih efektif terhadap perilaku personal hygine dalam mencegah keputihan pada remaja.

Hasil studi pendahuluan tanggal 12 Desember 2018 pada 15 orang pelajar di SMA Negeri 9 Pekanbaru dengan metode wawancara didapatkan data bahwa 9 pelajar hanya mengetahui HIV dan AIDS adalah suatu penyakit menular seksual dan tidak mengetahui penyebab dan upaya dalam pencegahannya. 6 orang pelajar lainnya mengatakan HIV dan AIDS merupakan suatu infeksi virus yang tertular akibat melakukan seks bebas dan dapat tertular dengan penggunaan barang secara bersamaan dengan orang yang positif HIV, seperti penggunaan sendok, gelas dan mandi di kolam renang umum. 
Arif Wira Dinata, Gamya Tri Utami, Reni Zulfitri, Pengaruh Pendidikan Kesehatan Melalui Audiovisual Terhadap Motivasi Remaja Dalam Upaya Pencegahan HIV/AIDS

Hasil wawancara dengan guru bimbingan konseling didapatkan data bahwa penyuluhan hanya dilakukan sekali dalam satu tahun dari pihak kepolisian terkait narkoba dan dari Puskesmas Kecamatan Lima Puluh terkait kesehatan reproduksi. Tingginya dorongan remaja dalam mengikuti penyuluhan tergantung seberapa menariknya narasumber dalam memberikan penyuluhan.

Penelitian ini bertujuan untuk melihat pengaruh pendidikan kesehatan melalui audiovisual terhadap motivasi remaja dalam upaya pencegahan HIV/AIDS.

\section{METODE PENELITIAN}

Penelitian ini merupakan jenis Quasy Experiment dengan rancangan Non-Equivalent with Control Group. Populasi penelitian ini adalah seluruh siswa dan siswi kelas X dan XI SMA Negeri 9 Pekanbaru sebanyak 672 orang. Teknik pengambilan sampel yang digunakan adalah stratified random sampling yaitu penetapan sampel dengan cara membuat strata sehingga setiap starta mewakili dalam penentuan sampel penelitian. Jumlah sampel yang diteliti sebanyak 90 responden yang terbagi menjadi 2 kelompok yaitu 45 orang kelompok eksperimen dan 45 orang kelompok kontrol.

Instrumen untuk pengumpulan data berupa lembar kuesioner. Kuesioner untuk mengukur sikap/motivasi remaja dalam upaya pencegahan HIV/AIDS menggunakan skala likert yang telah dilakukan uji validitas dan reliabilitasnya pada siswa dan siswi SMA Negeri 6 Pekanbaru.

Penelitian ini menggunakan analisa data univariat dan bivariat. Tujuan dari melakukan analisis univariat ini adalah untuk mengetahui data demografi responden penelitian meliputi usia, jenis kelamin, agama, dan tinggal bersama siapa responden di Pekanbaru. Selanjutnya untuk melihat perbedaan nilai pre test dan nilai post test kelompok eksperimen dan kelompok kontrol menggunakan Uji Wilcoxon, sedangkan untuk melihat perbadingan hasil nilai post test pada kedua kelompok menggunakan Uji Independent T-Test.

\section{HASIL PENELITIAN}

\section{A. Analisa Univariat}

1. Karakteristik Responden

\section{Tabel 1}

Distribusi karakteristik usia, jenis kelamin, dan agama

\begin{tabular}{|c|c|c|c|c|c|c|c|}
\hline \multirow[t]{2}{*}{ Karakteristik } & \multicolumn{2}{|c|}{$\begin{array}{c}\text { Kelompok } \\
\text { Eksperimen } \\
\text { (45) }\end{array}$} & \multicolumn{2}{|c|}{$\begin{array}{c}\text { Kelompok } \\
\text { Kontrol } \\
(45)\end{array}$} & \multicolumn{2}{|c|}{$\begin{array}{l}\text { Jumlah } \\
(n=90)\end{array}$} & \multirow[t]{2}{*}{$\begin{array}{c}P \\
\text { value }\end{array}$} \\
\hline & $\mathbf{n}$ & $\%$ & $\mathbf{n}$ & $\%$ & $\mathbf{n}$ & $\%$ & \\
\hline \multicolumn{8}{|l|}{ Usia } \\
\hline a. 15 tahun & 12 & 26,7 & 7 & 15,6 & 19 & 21,1 & \multirow{3}{*}{0,944} \\
\hline b. 16 tahun & 7 & 44,4 & 23 & 51,1 & 43 & 47,8 & \\
\hline c. 17 tahun & 13 & 28,9 & 15 & 33,3 & 28 & 31,1 & \\
\hline \multicolumn{8}{|l|}{ Jenis Kelamin } \\
\hline a. Laki-laki & 21 & 46,7 & 10 & 22,2 & 31 & 34,4 & \multirow{2}{*}{0,027} \\
\hline b. Perempuan & 24 & 53,3 & 35 & 77,8 & 59 & 65,6 & \\
\hline \multicolumn{8}{|l|}{ Agama } \\
\hline a. Islam & 41 & 91,1 & 38 & 84,4 & 79 & 87,8 & \multirow[t]{2}{*}{0,520} \\
\hline b. Kristen & 4 & 8,9 & 7 & 15,6 & 11 & 12,2 & \\
\hline
\end{tabular}

Tabel 1 menyatakan sebagian besar responden berusia 16 tahun yaitu sebanyak 43 orang $(47,8 \%)$, berjenis kelamin perempuan sebanyak 59 orang $(65,6 \%)$. Mayoritas responden beragama Islam sebanyak 79 orang $(87,8 \%)$, dan 
seluruh responden tinggal bersama keluarga yaitu 90 orang $(100 \%)$.

\section{Skor motivasi remaja terhadap pencegahan HIV /AIDS}

\section{Tabel 2}

Distribusi skor motivasi remaja sebelum dan setelah diberikan perlakuan pada kelompok eksperimen dan tidak dilakukan perlakuan pada kelompok kontrol.

\begin{tabular}{lcccc}
\hline \multicolumn{1}{c}{ Variabel } & n & Median & Min & Max \\
\hline $\begin{array}{l}\text { Motivasi } \\
\text { Kelompok }\end{array}$ & & & & \\
Eksperimen: & & & & \\
Pre test & 45 & 41,00 & 30 & 48 \\
Post test & 45 & 50,00 & 39 & 59 \\
\hline Motivasi & & & & \\
Kelompok & & & & \\
Kontrol: & & & & \\
Pre test & 45 & 45,00 & 33 & 51 \\
Post test & 45 & 44,00 & 36 & 52 \\
\hline
\end{tabular}

Tabel 2 dapat disimpulkan nilai post test lebih tinggi dari nilai pre test pada kelompok eksperimen, sedangkan untuk kelompok kontrol nilai pre test lebih tinggi dari nilai post test.

\section{B. Analisa Bivariat}

\section{Uji homogenitas pre test motivasi remaja} pada kedua kelompok penelitian

\section{Tabel 3}

Uji homogenitas pretest motivasi remaja pada kelompok eksperimen dan kelompok kontrol

\begin{tabular}{lcccc}
\hline \multicolumn{1}{c}{ Motivasi } & n & Median & SD & p value \\
\hline $\begin{array}{l}\text { Kelompok } \\
\text { eksperimen }\end{array}$ & 45 & 41,00 & 4,879 & \\
$\begin{array}{l}\text { Kelompok } \\
\text { kontrol }\end{array}$ & 45 & 45,00 & 4,043 & 0,073 \\
\hline
\end{tabular}

Berdasarkan tabel 3 menunjukkan bahwa hasil uji homogenitas pre test pada kelompok eksperimen dan kelompok kontrol didapatkan $p$ value $0,073>\alpha=0,05$.

\section{Perbedaan nilai motivasi remaja terhadap pencegahan HIV/AIDS}

\section{Tabel 4}

Perbedaan nilai motivasi remaja terhadap pencegahan HIV/AIDS sebelum dan sesudah diberikan perlakuan pada kelompok eksperimen dan sebelum dan sesudah tanpa diberikan perlakuan pada kelompok kontrol.

\begin{tabular}{lcccc}
\hline \multicolumn{1}{c}{ Variabel } & Median & $\begin{array}{c}\text { Perubahan } \\
\text { Median }\end{array}$ & SD & P value \\
\hline $\begin{array}{l}\text { Motivasi } \\
\text { Eksperimen }\end{array}$ & & & & \\
Pre test & 41,00 & 9,00 & 4,879 & 0,000 \\
$\begin{array}{l}\text { Post test } \\
\text { Motivasi }\end{array}$ & 50,00 & & 3,982 & \\
Kontrol & & & & \\
Pre test & 45,00 & & 4,043 & 0,440 \\
Post test & 44,00 & $-1,00$ & 3,709 & \\
\hline
\end{tabular}

Berdasarkan tabel 4 menunjukkan terdapat perbedaaan signifikan antara hasil median motivasi remaja pre test dan post test diberikan intervensi terhadap pencegahan HIV/AIDS pada kelompok eksperimen dengan $p$ value $(0,000)<\alpha$ $(0,05)$. Sedangkan pada kelompok kontrol tidak terdapat perbedaan motivasi sebelum dan setelah tanpa diberikan intervensi ( $p$ value 0,440 ).

3. Perbandingan motivasi remaja dalam upaya pencegahan HIV/AIDS pada kelompok eksperimen dan kelompok kontrol

\section{Tabel 5}

Perbandingan motivasi remaja terhadap pencegahan HIV/AIDS post test diberikan intervensi keperawatan pada kelompok eksperimen dengan tidak diberikan intervensi keperawatan pada kelompok kontrol.

\begin{tabular}{lccccc}
\hline \multicolumn{1}{c}{ Variabel } & n & Mean & $\begin{array}{c}\text { Perubahan } \\
\text { Mean }\end{array}$ & SD & P Value \\
\hline $\begin{array}{l}\text { Post test } \\
\text { Eksperimen }\end{array}$ & 45 & 49,78 & & 3,982 & \\
$\begin{array}{l}\text { Post test } \\
\text { Kontrol }\end{array}$ & 45 & 44,47 & 5,31 & 3,709 & 0,000 \\
\hline
\end{tabular}

Data tabel 5 menunjukkan hasil uji independent t test didapatkan $p$ value $(0,000)<\alpha$ $(0,05)$, sehingga $\left(\mathrm{H}_{0}\right)$ ditolak. Kesimpulannya adalah pendidikan kesehatan melalui audiovisual 
Arif Wira Dinata, Gamya Tri Utami, Reni Zulfitri, Pengaruh Pendidikan Kesehatan Melalui Audiovisual Terhadap Motivasi Remaja Dalam Upaya Pencegahan HIV/AIDS

berpengaruh terhadap motivasi remaja dalam upaya pencegahan HIV/AIDS.

\section{PEMBAHASAN}

\section{A. Karakteristik Responden}

1. Usia

Peneliti membagi usia responden menjadi 3 kelompok. Masa remaja terbagi menjadi masa remaja awal yaitu berusia 11-14 tahun, selanjutnya masa remaja pertengahan yaitu usia 15-17 tahun dan selanjutnya adalah masa remaja akhir yaitu usia 18-20 tahun (Potter \& Perry, 2011). Hasil analisis karakteristik usia responden yang dilakukan terhadap 90 responden, didapatkan responden terbanyak sedang berada pada masa remaja pertengahan yaitu berusia 16 tahun sebanyak 43 orang $(47,8 \%)$.

Pada masa remaja pertengahan ini remaja hampir melengkapi tahap pubertas, timbul rasa cinta dan mempererat hubungan dengan lawan jenis, serta terjadi peningkatan kadar hormon seks, sehingga menimbulkan dorongan motivasi seksual, apabila tidak dikontrol dengan baik maka akan menyebabkan masalah kesehatan khususnya kesehatan reproduksi (Ghebremicheal \& Finkelman, 2013).

\section{Jenis Kelamin}

Hasil penelitian ini didapatkan responden terbanyak berjenis kelamin perempuan yaitu 59 orang $(65,6 \%)$. Hal ini terjadi dikarenakan jumlah siswi dalam setiap kelas lebih banyak dibandingkan jumlah siswa serta berdasarkan teknik pengambilan sampel yang sudah ditetapkan oleh peneliti.

Christopherson dan Conner (dalam Dewi, 2012) mengatakan untuk faktor sosial, remaja laki-laki cenderung lebih diberi kebebasan dalam pergaulan dan perempuan lebih patuh terhadap aturan hukum karena orang tua cenderung lebih protektif terhadap remaja perempuan. Faktor lain yang berkontribusi pada resiko terjadinya perilaku seksual adalah perkembangan kognitif, psikologi dan seksual dimana remaja laki-laki memiliki keberanian tinggi dan lebih berani mengambil resiko terhadap tindakan yang dilakukannya, sehingga perbedaan perkembangan aspek kognitif, psikologis dan seksual diantara remaja laki-laki dengan perempuan, serta nilai atau norma yang ada ditengah-tengah masyarakat Indonesia mendukung remaja laki-laki berperilaku beresiko lebih banyak dibanding perempuan (Dewi, 2012).

\section{Agama Responden}

Hasil penelitian menunjukkan bahwa agama responden mayoritas Islam yaitu 79 responden (87,8\%). Agama merupakan landasan dalam kehidupan seseorang karena didalamnya diatur tentang cara berperilaku, bersikap dan bertindak serta didalamnya terdapat nilai dan norma yang harus ditaati. Hal ini didukung oleh penelitian Handayani (2016), dimana tingginya pemahaman seseorang tentang agama akan berpengaruh terhadap perilaku dalam kehidupan sehari hari, 
Jurnal Ners Indonesia, Vol. 12, No. 1, September 2021

seperti tidak melakukan seks sebelum menikah. Seseorang remaja yang pemahaman agamanya baik maka akan memiliki rasa takut untuk melakukan perbuatan yang bertentangan dan dilarang oleh agamanya.

\section{B. Perbedaan motivasi remaja terhadap pencegahan HIV/AIDS}

\section{Kelompok Eksperimen}

Hasil analisis pengaruh pendidikan kesehatan melalui audiovisual terhadap motivasi remaja terhadap pencegahan HIV/AIDS didapatkan median hasil dari pengukuran setelah diberikan intervensi mengalami peningkatan. Ini terjadi karena pada kelompok eksperimen diberikan intervensi keperawatan yaitu pendidikan kesehatan tentang konsep dan upaya pencegahan HIV/AIDS selama lebih kurang 45 menit dengan menggunakan media audiovisual.

Hasil uji Wilcoxon yang dilakukan pada kelompok eksperimen sebelum dan sesudah diberikan intervensi keperawatan berupa pendidikan kesehatan melalui audiovisual diperoleh $p$ value $(0,000)<\alpha(0,05)$ dan perbedaan median motivasi remaja sebelum dan sesudah diberikan intervensi keperawatan yaitu 9,00 sehingga disimpulkan terdapat peningkatan motivasi remaja terhadap upaya pencegahan HIV/AIDS setelah diberikan intervensi keperawatan.

Memberikan suatu pendidikan kesehatan bisa menggunakan berbagai metode, cara dan media yang digunakan, contohnya media yang bisa digunakan untuk menyampaikan informasi yang lebih menarik dalam memberikan pendidikan kesehatan adalah dengan menggunakan audiovisual. Juliantara (2009) menyatakan bahwa pendidikan kesehatan menggunakan media audiovisual akan memperlihatkan suara dan gambar dengan serentak pada saat menginformasikan suatu informasi. Hal ini sejalan menurut penelitian Fitriani (2011), yang menyatakan bahwa dalam mendapatkan pengetahuan serta motivasi mengenai ilmu kesehatan seperti cara sehat yang dapat mempengaruhi seseorang yaitu dengan cara promosi kesehatan, sehingga mereka mengerti dan dapat menerapkan prinsip-prinsip pencegahan penyakit dan keselamatan dalam kehidupan sehari-hari.

\section{Kelompok Kontrol}

Hasil analisis bivariat menggunakan uji Wilcoxon pada kelompok kontrol menunjukkan bahwa tidak ada pengaruh baik sebelum dan sesudah tanpa diberikan intervensi keperawatan. Tidak adanya perubahan motivasi remaja pada kelompok kontrol terhadap upaya pencegahan HIV/AIDS, sehingga responden terhambat untuk mendapatkan informasi secara baik dari pemberian pendidikan kesehatan melaui audiovisual ini, meskipun juga mendapatkan pendidikan kesehatan melalui audiovisual setelah dilakukannya post test dan juga mendapatkan informasi seputar HIV/AIDS dari keluarga, teman dan juga dari media sosial. 
Arif Wira Dinata, Gamya Tri Utami, Reni Zulfitri, Pengaruh Pendidikan Kesehatan Melalui Audiovisual Terhadap Motivasi Remaja Dalam Upaya Pencegahan HIV/AIDS

C. Perbandingan motivasi remaja dalam pencegahan HIV/AIDS setelah diberikan pendidikan kesehatan menggunakan audiovisual pada kelompok eksperimen dan tanpa diberikan pendidikan kesehatan melalui audiovisual pada kelompok kontrol.

Berdasarkan hasil uji statistik didapatkan hasil bahwa terdapat perbedaan nilai mean motivasi remaja dalam upaya pencegahan HIV/AIDS antara kedua kelompok (ekperimen dan kontrol). Setelah diberikan intervensi keperawatan, terjadi kenaikan motivasi pada remaja di kelompok eksperimen. Hal ini dikuatkan oleh penelitian Santi (2014) tentang pemberian pendidikan kesehatan menggunakan audiovisual efektif terhadap perubahan tindakan masyarakat dalam pencegahan filariasis.

Kamtono, Nurhayati, dan Wulandari (2016) mengatakan agar tujuan dalam memberikan pendidikan kesehatan tercapai, maka harus memperhatikan berbagai hal, antara lain adalah media dan metode. Menurut Widyanto (2014), informasi yang diberikan melalui media visual (poster, leaflet, selebaran) itu akan tersimpan lebih sedikit yaitu 20\% dari pada media audiovisual (film maupun video) yaitu $50 \%$ dan apabila dilaksanakan dalam praktik nyata itu akan tersimpan di ingatan seseorang sebanyak $70 \%$.

Penelitian lain yang dilakukan oleh Kapti (2013) bahwa audiovisual efektif sebagai media penyuluhan kesehatan terhadap peningkatan pengetahuan dan sikap ibu terhadap tatalaksana balita dengan diare. Hal ini juga dikuatkan dari penelitian Mayanti (2016) terhadap 84 responden, bahwa ada perbedaan yang signifikan antara median sebelum dan setelah diberikan pendidikan kesehatan dengan menggunakan media audiovisual terhadap peningkatan sikap dalam pencegahan kanker serviks.

\section{SIMPULAN}

Berdasarkan karakteristik usia responden terbanyak adalah 16 tahun (47,8\%), sebagian besar berjenis kelamin perempuan $(65,6 \%)$, mayoritas beragama Islam $(87,8 \%)$ dan seluruh responden sedang menempuh pendidikan tingkat SMA dan tinggal bersama keluarga. Hasil analisis statistik didapatkan p value $(0,000)<\alpha(0,05)$, sehingga dapat disimpulkan pemberian pendidikan kesehatan melalui audiovisual berpengaruh meningkatkan motivasi remaja dalam upaya pencegahan HIV/AIDS.

\section{SARAN}

Disarankan kepada penanggung jawab bidang akademik dan kesiswaan memberikan edukasi dan motivasi kepada siswa untuk pencegahan HIV/AIDS.

\section{DAFTAR PUSTAKA}

Banun, F. O., \& Setyorogo, S. (2013). Faktorfaktor yang berhubungan dengan perilaku seksual pranikah pada mahasiswa semester V STIKes X Jakarta Timur 2012. Jurnal Ilmiah Kesehatan, 5(1), 12-19.

Dewi, A. P. (2012). Hubungan karakteristik remaja, peran teman sebaya dan paparan pornografi dengan perilaku seksual remaja 
di kelurahan pasir gunung selatan depok. Depok: Fakultas Ilmu Keperawatan Universitas Indonesia.

Dinas Kesehatan Kota Pekanbaru. (2018). Rekap laporan kasus HIV/AIDS tahun 2018. Dinas Kesehatan Kota Pekanbaru. Diperoleh pada tanggal 31 Oktober 2018.

Departemen Kesehatan RI. (2009). Laporan riset kesehatan dasar. Jakarta

Ghebremichael, M. S., \& Finkelman, M. D. (2013). The effect of premarital sex on sexually transmitted infections (STIs) and high risk behaviors in women. Journal of AIDS and HIV research (Online), 5(2), 59. Diperoleh pada tanggal 22 Mei 2019 dari https://www.ncbi.nlm.nih.gov/pmc/articles/ PMC3634578/pdf/nihms450301.pdf

Handayani, L. (2016). Penanaman nilai-nilai moral dalam keluarga beda agama. (Studi kasus pada tiga keluarga Islam dan Kristen di Desa Doplang Kecamatan Bawen Kabupaten Semarang). (Doctoral dissertation, IAIN Salatiga). Diperoleh tanggal $20 \quad$ Mei 2019 dari http://erepository.perpus.iainsalatiga.ac.id/i d/eprint/717

Fitriani, S. (2011). Promosi kesehatan. Yogyakarta: Graha Ilmu

Juliantara. (2009). Pendekatan pembelajaran konvensional. Jakarta: EGC

Kementerian Kesehatan Republik Indonesia. (2018). Profil kesehatan Indonesia tahun 2017. DKI Jakarta: Kemenkes RI

Nasir, A. \& Muhith, A. (2011). Dasar-dasar keperawatan jiwa: pengantar \& teori. Jakarta: Salemba Medika

Nursalam \& Efendi, F. (2008). Pendidikan dalam keperawatan. Jakarta: Salemba Medika

Notoatmodjo, S. (2010). Ilmu perilaku kesehatan. Jakarta: Rineka Cipta

Potter, P. A., \& Perry, A. G. (2009). Fundamental of nursing. $\left(7^{\text {th }}\right.$ ed). Jakarta: Salemba Medika

Santi, S. M., Sabrian, F., \& Karim, D. (2014). Efektifitas pendidikan kesehatan menggunakan media audiovisual terhadap perilaku Pencegahan filariasis. Jurnal Online Mahasiswa (JOM) Bidang Ilmu Keperawatan, 1(2), 1-8.

Setiyorini, E. (2015). Quality of life people living with HIV-AIDS (PLWHA) with antiretroviral therapy in cendana clinic ngudi waluyo wlingi hospital. Jurnal Ners dan Kebidanan (Journal of Ners and Midwifery), 2(1), 006-014. Diperoleh tanggal 10 Januari 2019 dari http://jnk.phb.ac.id/index.php/jnk/article/vie wFile/49/47

Seotjiningsih. (2010). Tumbuh kembang remaja dan permasalahannya. Jakarta: Sagung Seto

UNAIDS. HIV And AIDS Estimates. (2017). Joint united nations programme on HIVIAIDS (UNAIDS). Diperoleh pada tanggal 1 November 2018 dari http://apps.who.int/iris/bitstream/10665/250 441/1/9789241565394-eng.pdf?ua=1

Willis, S. S. (2012). Remaja dan masalahnya. Bandung: Alfabeta

Wong, D. L. (2009). Buku ajar keperawatan pediatric. (Marilyn, H. E., David, W., Marilyn, L.W., \& Patricia, S, Penerjemah) (6 th, volume 1). Jakarta: EGC

Widyanto, F. C. (2014). Keperawatan komunitas dengan pendekatan praktis. Yogyakarta: Nuha Medika

Yulistasari, S., Dewi, A.P., \& Jumaini. (2014). Efektivitas pendidikan kesehatan menggunakan media audiovisual terhadap perilaku personal hygiene (genitalia) remaja putri dalam mencegah keputihan. Jurnal Online Mahasiswa (JOM) Bidang Ilmu Keperawatan, 1(1). Diperoleh tanggal 4 November 2018 dari https://media.neliti.com/media/publications/ 186687-ID-efektivitas-pendidikankesehatan-menggun.pdf

Wong, D. L. (2009). Buku ajar keperawatan pediatrik.Jakarta:EGC 